\title{
THE PEOPLE OF ONDO KINGDOM AND THEIR CULTURE: A HISTORICAL SURVEY AND POLITICAL UNDERPINNING
}

\author{
Oyejide Felix Omotosho ${ }^{1 *}$, Derin K. Ologbenla ${ }^{2}$, Oluwatobiloba-Oyejide Alex \\ Omotosho ${ }^{3}$, Oluwatomilayo Felicity Omotosho ${ }^{3}$ \\ ${ }^{1}$ Dr. Political Science Department, The University of the Gambia, Brikama, THE GAMBIA, \\ ofomotosho@utg.edu.gm, fomotosho1967@yahoo.com \\ ${ }^{2}$ Prof. Political Science Department, University of Lagos, Akoka, Yaba, Lagos, NIGERIA, \\ dologbenla@unilag.edu.ng, derin ologbenla@yahoo.com \\ ${ }^{3}$ Department of Nursing and Reproductive Health, The University of the Gambia, Banjul, THE \\ GAMBIA, ooalex@utg.edu.gm; omotoshoalex@yahoo.com \\ ${ }^{*}$ Corresponding Author
}

\begin{abstract}
In every given nation, particularly those of Africa, with strong tribal affiliations, different groupings exist as tribes with their peculiar languages and dialects, amidst totality of the culture that unifies as a people. With the advent of colonialism, a change occurred as some of these tribes scattered about and could no longer be grouped together as one indivisible entity/nation. Among the affected tribes affected were the Yoruba in the western part of Nigeria, with its sub-groups like the Ondos in present day Ondo state, having migrated from the old Oyo Empire. This research traced the historical links of the Ondos in Ondo Kingdom including their culture, settlement, influences and socio-political organizations which stand them unique. The research deemed searchlights into its organized traditional political structure with a comparative survey of the modern Nigerian political practice of federalism and seeing how the indigenes of Ondo Kingdom have been found to be very efficient and efficient bureaucrats and technocrats, both in the public sector and private industry. A descriptive, analytical- method of exploration was used to accounts for the origins and socio-political influences of the Ondo people. The paper appraises the distortions of facts about the people's history and descent, while, seeking clarifications for consensus reached by social sciences scholars and historians, using the comparative analysis approach. Findings confirmed that the Ondo indigenes are a group of Yoruba, whose mother, the favorite wife of the Alafin Oluaso called "Olu", was sent away from the palace some six centuries back after birth of a twins to prevent their slaughter, since it was an abomination to have such a mysterious birth at that time in the empire. The research confirmed that the Ondos, emerged as very industrious and assertive sub-group of Yoruba and descendants of Lamurudu the father of Oduduwa, with their industrious nature in industry, agriculture, government and education.
\end{abstract}

Keywords: Ondo People, Yoruba Tribe, Dialect, Culture, Settlement

\section{INTRODUCTION}

Recent study in the social sciences and humanities have proven the need for research into culture and development, in relation, to their significance to society and how to recollect the past and connect this to the present for the shaping of a viable and memorable future (Omotosho et al, 2016). This necessitated this research study for the purpose of carrying out investigations into the origins and cultures of a people called 
the Ondo indigenes of the South-West. Such study also helps the researchers to build upon current trends for sake of knowledge production and contributions to research in some ways and in larger ways, to guarantee a viable nationhood that is sustaining and long-lasting (Heywood, 2007, Omotosho et al, 2016). Through recollections of histories, people are able to trace their origins and align properly with their affinities and sources. A nation like Nigeria, which comprises of diverse elements that make it up from independence is able to identify its identities, form its cultures, and craft its national symbols and signs for national integration and good co-existence. All of these cannot be achieved without a visit to the past and when the past cannot be traced, a nation may be existing in vacuum and obscurity. This could cave in to disintegration in the form of secession and break up, which the country suffered from in the late sixties as a result of political differences and colonial distortions that tended to interpret Nigerians as different nations and not one entity (Abimbola, 1977). Till date, the country and many other sub-Saharan nations like the Central African Republic, South Sudan, even the Gambia, as small as it is, to name a few are still battling with the problem of unity and belonging which undermine national ethos, development and genuine integration (Johnson, 1921, Abimbola, 1977). This research explores the origins and cultures of the Yoruba of Nigeria, with focus on the Ondo sub-group and the relevance of their co-existence to the cultural values, ethics and development processes of the country called Nigeria and how best the nation can be best united for national integration.

\section{WHO ARE THE "ONDOS” AND WHAT IS THEIR ROOT?}

In the South - Western part of the present day Nigeria is the large and dominant ethnic group of Yoruba. This group, which again was sub-grouped into two descent systems of the south and north, comprising of several sub-ethnic groupings who all speak the same Yoruba language but with different dialectical intonations, has the Ondo Kingdom in its southern part with cognatic descent system. Cognatic descent system is one in which the descent of an individual can be traced through his ancestor in 'both male and female lines' (Bender, D. R. 1970: 71 - 81; and Eades, J. S., 1980). This means that, while an individual in the northern kingdom can identify with only one descent group known as 'agnatic' which is patrilineal, the cognatic to which Ondo belongs allows for an individual to identify with both patrilineal and matrilineal (Bender, D. R., 1970; Eades, J. S., 1980; Johnson, S., 1921; and Ajulo, E. B., 2000).

Nigeria is divided into six geo-political zones with thirty-six states, as a federation, together with the Federal Capital Territory, Abuja, being the thirty-seventh. Among these states is the Sunshine State called Ondo in the South-West, where the Ondo Kingdom resides. It is sitting among the thickly forested planes, with several towns and villages, and located some $300 \mathrm{~km}$ to the North-East of Lagos, Nigeria's economic nerve centre and $45 \mathrm{~km}$ away from Akure, the Ondo State Capital with all accessible ways from all parts of the country (Pls, see, http://kwekudee-tripdownmemorylane.blogspot.com/2014/09/ondo-people-forestagriculturalist.html).

Its weather elements are those typifying the rainforest region of sub-Saharan Africa, mitigated by its surrounding thick forests which are blessed with. It is peopled by those indigenes whose paternity is traceable to Oduduwa, the son of Lamurudu, who was believed to have migrated from Mecca, Saudi Arabia, after some sectarian dispute to the present day lle-Ife, the cradle of the Yoruba, where he gave birth to Oduduwa and the latter gave birth to another sixteen sons, among them, Oranmiyan, who later became the Alaafin of Oyo, and who according to descent gave birth to Oluaso, the father of Pupupu, a female child, who went to found the Ondo Kingdom from far away Oyo (Eades, J. S., 1980). However, as in most historical collections, the history of the ondo origin is not without some controversies, as there are three different versions that purport to explain it. This controversy arose in consequence of lack of written records, as at then, supporting the clear and unambiguous account that are embraced, home and abroad, by the Ondo indigenes in the one part and the entire Yoruba race in the other part, including their historians and other scholars, within the intellectual circle. This paper is meant to actually add to what we now have today as contemporary facts to the available schools of thought that have attempted to explain the etymological root of the Ondo Kingdom, its people and their ubiquitous culture (Johnson, S., 1921 and see no. 13).

According to Olupona, (1991), Ondo kingdom, which shares boundary with modern Akure metropolis in Ondo State and Obokun areas of llesha in neighboring Osun State forms its boundary in the north and in the south with Ilaje/Eseodo Local Government Areas, terminating at Owena River in the Ifedore Local Government Area in the West, stretching farther to River Ooni, where Okeigbo, an adjourning town with mainly original Ife settlers, now part of Ondo division situates, ....... "While the people of the kingdom, almost in unison rejected a version that links its origin to the Old Benin Kingdom in present day Edo State as being the invention of its proponents, there seems to be some convergence on the other two accounts that trace the origin of the people to Ife and Oyo respectively" (Please, see http://kwekudee-tripdownmemorylane. blogspot.com/2014/09/ondo-people-forest-agriculralist.html, http://ekimogundescentdant.org/index.php? 
IJASOS- International E-Journal of Advances in Social Sciences, Vol. VI, Issue 17, August 2020

option=com, content\&new=article\&id=117:ondo-kingdom-landmarks-, http://ekimogundescendant.org, and http://irepos.unijos.edu.ng/ispui/bitstream/123456789/157/1/yoruba\%20ondo\%20prov erb.pdf).

According to legend, Pupupu, a female, was one of the twin children of Oba Oluaso, who reigned in Oyo Empire in the $15^{\text {th }}$ century, some over 500years ago. The twin brother, a male was called Orere. Legend informed us that, in those days, twin birth was an abomination as it was considered a serious calamity if they were spared. This time around, the birth came to the king in the palace who could not afford to spare them, but for his royal love for one of his wives called 'Olu', who gave birth to the mysterious babies, her life and the twins' were spared. To avert the imminent calamity believed to be associated with this occurrence on the land, the king Oluaso instructed that one of his great hunters called 'lja' escort Olu and her babies in company of some slaves that would be serving them on the way out of the empire into the far thick forest, never to return.

Before their departure, the Alaafin, after offering prayers, gave them a beaded crown and an Akoko tree, signifying their royalty with which they were to be welcomed anywhere they tarried or decided to settle. This was exactly what happened in places they reached until finally they got to their present final settlement, where they were welcomed unrestricted and allowed to take possession and authority. Asides, their father (Oluaso), against the tradition of the multitribal marks of Oyo, incised the twins with two long tribal marks as an identity and for recognition in case of future. This explains the origin of the tribal marks of Ondo till date. The political underpinning in this respect is in two ways. The first, being the way the 'Royal Might' was used to escape the mysterious babies out of the palace instead of being killed as it would ordinarily not have happened, which made possible the emergence of two communities today known as the Ondo Kingdom (the twin girl) and Ile-Oluji (the twin boy). The second dimension was the royal identification that portrayed them as royal children and so, anywhere they reached, they should be accorded royal welcome, culminating into why Pupupu was allowed kingship authority without resistance at 'Edo du do' now Ondo by the original settlers of the land, Idoko, Ifore and Oka people. Today, the Ondo people, anywhere they are and in anything they are doing, they are always influential and on the lead. Indeed, empirical facts confirm that Ondo indigenes are good administrators and managers of human and material resources. They travel a lot and are very industrious and enterprising. If an Ondo man/woman reaches a desert, he/she will turn it to a mega city, through enterprising and hard work. In education, they are on the lead, in socials and morals, the Ondo people are in the fore-front, in worship, they are renowned. In accommodating strangers, they are very kind, but, they could be wild and become very aggressive, if want to be manipulated or molested (Omotosho, F., Ologbenla, D. K. and Omotosho, A., 2016). In other words, as patient, kind and friendly as an Ondo man could be or appears and/or wishes to be, he could be provoked or become fury if undermined. This informs why one of their deities that they worship today is 'Ogun' (God of Iron), which, is celebrated every year as a festival, using dog, palm win and palm fronts as sacrifices to appease it.

\section{1. (a), The Emergence of the Ondo Kingdom(1510)}

The contingent moved and wandered through the forest until they arrived at a place called Epin, near Gbere, whose inhabitants were called Ibariba. They were well received and catered for until the death of Oba Oluaso in 1497. They then made attempts to return and arrived Oyo on account of unfair treatment by the succeeding king. Omogbogi, the reigning king then, who sent them back to a virgin land compassed about by Ife, ljesa, Ekiti, Ado (Benin) and ljebu communities. They later arrived on a second journey at a place called Igbo ljamo (the forest discovered by lja). The group stayed in this forest for a while, after which they found the forest unsafe and continued their journey eastward, until they finally got to a place called Epe,a town nearby the present Ondo town ( http://news2.onlinenigeria.com/news/general/42431-500-years-yearsthe-osemawe-dynasty.html, Johnson, S., 1921).

They were in Epe for many years and as they journeyed on, they passed through a hill which is today known as Oke Agunla and one of the communities that make up the present day Ondo Kingdom. From this hill, they spotted some smoke and headed in its direction. There, they met a man called 'Ekiri', one of the original inhabitants of the area. As was the usual practice then, the ifa oracle was consulted on the prospects of the newly found location. The oracle instructed them to take along a yam stake (edo) as their walking stick. The oracle informed them to poke the stick into the ground as they journeyed along and wherever they reached and the stick didn't bond with land, there was to be their final settlement (Olupona, J. K., 1991; Clarke, K. W. and http:// ekimogundescendant.org/).

Pupupu and her entourage continued their journey from Epe until they got to where the stick did not bond after they poked it, as instructed, and there, they chorused in surprise 'Edo du do' (The yam stake would not stick in) translating to mean 'Ondo' till today. On arrival, according to oral tradition, they met Ifore, the Idoko and the Oka inhabitants on the soil who recognized the royalty of the new arrivals and readily ceded to them 
the authority to rule over the territory, confirming, the underpinning factor of divine rulership, This was how the Ondo Kingdom was founded and Pupupu became the first female Ondo king called the Osemawe of Ondo land in the year 1510 (Please see, http://ekimogundescendant.org/index.php?option=com.content\& news=article\&id=117:ondo-kingdom-landmarks-).Thereafter, the people enlarged into a big empire with other established settlements like Igbindo, Igbado, Ilu-nla, Odigbo, Ajue, Igunshin just to name a few, but, however left Epe their spiritual source for all rituals and festivals, where they paid pilgrimages to perform different kinds of rituals and prayers. Till date, history has it that, even when any Osemawe dies, his/her head is usually buried at Epe, the original town of Ondo, while the rest of the body is buried in Ondo Kingdom, signifying (Orisun) that is 'source' and hence a political spectrum (Johnson, S., 1921; Olupona, J. K., 1991; Bascou, W. K., 1965). Politically now, Epe became a spiritual headquarter and the Osemawe palace in Ondo township became the governing throne. For the twin brother, Orere, a historical account had it that he (Orere) unlike Pupupu, now a king, journeyed a little farther from Ondo to settle in a place called lle-Oluji (the land of 'Olu' who never woke up again) and became its first traditional ruler. Till today, the word/name Orere is among the pedigree of the Olu of Ile-Oluji,which shares same tradition and history with his Ondo sister Pupupu, a town of about 9miles away, including festivals and rituals. They all are inhabited in the same state, Ondo, which was established by the General Murtala Ramat Mohammed military administration on $3^{\text {rd }}$ February, 1976 from the old Western region with a capital in Akure. Until 1996, when Ekiti State was split off from it by the Sanni Abacha regime (Omotosho, 2004), originally part of Ondo state.

One other political interference and underpinning, associated with the Ondo kingdom and its people were the imperialist and colonialist interferences of the $19^{\text {th }}$ century, when pressure from expanded European contact and crises from the Yoruba political wars paved ways for these whites to penetrate the hinterland from the Lagos colony, using Ondo as a route since the Osemawe throne had been weakened, thereby, making the colonizers to establish both trade and administrative links in Ondo town. With the expansion of the Atlantic slave trade and large scale population displacement in Yoruba land, the political life of the Ondo Kingdom changed, especially on land tenure system and hereditary lineage which resulted into intense internal rifts among its varying subjects then, culminating into division and chaos that weakened the throne. The throne of Pupupu was later toppled six years after, in a palace coup by another Osemawe (a man) called Aise, Pupupu's first son and that was how the royal throne shifted from female hereditary to male hereditary till today (Johnson, S., 1921; Abimbola, W., 1977: please, see, http://news2.onlinenigeria.com/news/general /42431-500-years-theosemawe-dynasty.html ,http://thenationonlineng.net/is-new-yam-feast-losing-its-taste). The Ondo people,given their royal nature, are so influential in their State and its government and they are known to be many in its public service. The former Executive Governor of the state, Dr. Olusegu Mimiko, a Medical Doctor by profession but politician by occupation is a true born son of Ondo Town (Babalola, S. A., 1966; Johnson, S., 1921 and Eades, J. S., 1980.

\section{TRADITIONAL INSTITUTIONAL STRUCTURE AND GOVERNMENT PROCESS OF THE ONDO KINGDOM:}

As Olupona (1991:195) infers, 'The system of government in Ondo Kingdom is rather an interesting one'. The focus is centralized on the election of a divine kingship with a king status, which is a hereditary one, rotating among five ruling houses (genealogies) namely Arilekolasi, Jisomosun, Aroworayi, Jilo and Fidipote, with an authority partly derived through the legendary fore-parent, Oba Pupupu, who migrated from Oyo and in the other part, from Oduduwa, the descent of the Yoruba race who derived (his) from 'Olodumare', the supreme being.

The next grade of chiefs are the 'Ekule' who number seven and lower in rank than the Eghae, carrying out ministerial functions of the kingdom such as treasury, information, attorney-general and justice, education and other special duties as assigned by the Eghae which they are responsible to. They are in this order; Odofin, Arogbo, Logbosere, Odofindi, Sagwe, Sara and Olotu-Omoba. After these seven are the lowest chieftaincy titled citizens of the kingdom called Elegbe and number 15. Their principal duty is law, order and general security of the land from both internal and xternal warlords. They of course constitute the armed forces. All these activities are well co-ordinated from the center headed by the Eghae and chairman-ed by the Osemawe. In other words, the kingdom operates one of quasi-federal systems that provide for an effective governance process like Senegal and South Africa respectively.

The 'Alaworo' priest chiefs are the next group of leaders in Ondo. These are largely heads of local, preOduduwa groups who are now in a position of 'ritual superiority' over the newcomers. They consist of Oloja Oke-Idoko, Ekiri of Ifore, Sora and Akunara, the last two being the Oramfe priests. All these titles are hereditary and candidates are elected from the family concerned. (see, http://ekimogundescendant.org/ , http://ekimogundescendant.org/indexphp?optio=com.content\&news=article=117:ondo-kingdom-landmarks- 
,http://kwekudee-tripdownmemorylane.blogspot.com/2014/09/ondo-people-forest-agriculturalist.html). In the institutional structure and government process of Ondo, the women are also highly formidable and influential with their own structure appearing like their male counterparts', playing prominent roles like the installation of a new Osemawe by the 'Lobun' the head of the market and kingmaker. History confirms that no one else installs a king in Ondo kingdom than 'Lobun' and after this installation, she goes to her own tent and would never see Osemawe again until she dies vis-à-vis. If a Lobun also dies, the king she installs must die on the throne before a new Lobun is installed, lest, if not installed, no new Osemawe would be installed. This is the tradition and would continue to be. Lobun is regarded as a woman king, who replaces female Osemawe like Pupupu the progenitor (Bender, D. R., 1970; Lloyd, P. C., 1962). Market is an important place in the institutional structure of Ondo as it is of economic and social significance in the day to day administration and commerce of the kingdom. It is controlled by the women under the authority of Lobun who is also the priestess Aje (god of wealth and prosperity). Till today, there is no economic life-wire of the kingdom and the Ondo state people in general that is not fascinated and strongly upheld by women, even, in modern day government. They are very enterprising, hardworking and very supportive to their husbands even during wars or troubles. Ondo women are very disciplined and brave like their progenitor Pupupu. They are responsible for discipline at homes, at work and farms, they are in charge of trade and their husband's wealth, they serve as advisors and guidance and they provide divinities. This is why their children are more disciplined and are afraid not to get involved in any crime of disgraceful act to their lineage because of their mothers' spanks, while the fathers remain petters, but highly industrious (please, see 13, 14, 17; Johnson, S., 1921; Olupona, 1991).

Olupona noted, "Once a Lobun is elected, it is forbidden for her to engage in any domestic work as she cannot step her feet on an unswept floor early in the morning and neither can she eat any food prepared the previous day". To this end, she has a retinue of staff that work for/with her to keep her health and she is to be catered for, for the rest of her life without working aside from royal assignment and market supervision by 'orders'. The women have a council like their male counterpart comprising Lisa-Lobun, Jomu-Lobun, Orangun-Lobun, Sasere-Lobun and Adafin. Asides, there are other female chiefs of lower grades and they include Odofin-Lobun, Ogede-Lobun, Sama-Lobun and Awoye-Lobun. The Eghae has the responsibility of selecting Lobun while the high female chiefs ekect the other female chiefs. Such appointments are approved by the Osemawe through Chief Sasere.

The Ondo people are also organized into a social structure of clannish system of compound life where the eldest son is the head of the home and his wife or wives remain mothers for the remaining boys in the family until that time they are old enough to marry. If the eldest dies, the most-senior boy of his own eldest son could take-over the wives for marriage, even though, he too already has his own wife or wives, just purposely to provide care for the women and their children, again, should such women still want to give birth, they have someone to impregnate them. So, life continues invariably. Indeed, in those days, this culture cuts across all Yoruba race until modernity stopped most of these beliefs and practices. The social institutional lineages also play prime functions in the government process of the kingdom as they offer forums for home discipline and recruitments for major public functions.

\section{THE UNDERPININGS TO THE ORGANIZED POLITICAL SYSTEM OF ONDO KINGDOM}

The rich and strong political formations of the Ondo Kingdom and its people have had some positive implications to the experience of the Ondo indigenes in public-sector management and private business. Their organized system has offered an average Ondo man/woman the privileges of leadership abilities and ethical values, most especially, in the unique way (s) he/she performs or excels in resource management and people administration. Not only that, their crave for modern education and love for philosophy have added additional impetus to how they excel in public life as technocrats, bureaucrats and businessmen and women across the world, not only in Nigeria. Hence, the Ondo indigenes are skilled in handling public issues and problems through their efficient and highly-knowledgeable talents in management and enterprise.

Nigeria operates a federal political system, with organized institutions that are duplicated and structured into three legislative lists for effective governance deliveries. With the centralized but some fundamental devolution of powers to other levels of authorities in the kingdom, coupled with the rich cultural heritage the people inherited from their fore-fathers and the passion they have for education and public life practice, the Ondo indigenes become craftier in management and industry than other sub-group of the Yoruba. The development that has seen many indigenes of Ondo and its environs to be very successful public managers and industrialists. Many Ondo indigenes are therefore found in government today, both at federal, state and local levels of government. They have also been found to be very successful at the international level as 
industrious and energetic people (Olupona, 1991).

\section{CULTURAL VALUES OF THE ONDO PEOPLE IN ONDO KINGDOM}

The Ondo people are also blessed with rich culture of various brands like festival celebrations, ritual marriages, rites performance as mentioned already, drumming and dancing, arts and crafts like blacksmithing, clothes'dyeing called 'Aso Adire', dressing, funerals, tribal marks, cultism, ancestral worships and traditional sacrifices, all of which are incorporated in their African Traditional Religion. Prominent among these festivals are the Ogun festivals (god of iron) celebrated between the months of August and September every year. According to Olupona, the preparation for the festival commences 17days before the actual Ogun day at the appearance of the new moon, with spectrum of rituals performed to welcome and appease the god of iron, with the use of 'upe', a long gourd trumpet blown early in the morning of the ceremony day in the house of Ayadi, the ritual specialist of Ogun public worship (Olupona, 1991; Bascom, 1965). Such trumpeting lasts seven days, believed to be very symbolic. The festival involves many stages this research is not opportune to provide due to limitation of study. The festival attracts eminent sons and daughters of the kingdom to Ondo to grace it as an honor, also for blessing and protection. Today, the festival has drawn in government's attention with its officials attending the celebrations, portending official recognitions of the rituals and the significance to economy and and the soci-political life of the state in a broad sense. For example, we often see government ministers, commissioners especially those of culture and tourism, information and culture and National Orientation, Chieftaincy affairs and even the state governors attending in person. The festival, hence, by implication, provides a good forum for political gatherings for sensitization and mobilization.

When Ayadi ushers Ogun in (the god), he must sacrifice dogs (aja) and tortoise (aghon) which some other Yoruba called 'ljapa', and pour libations at the shrine of Ogun. Dog is believed to be the Ogun's favourite's meat, thus, may assume all Ondo indigenes eat it, but not in all cases. During Ogun festival, dogs are ususlly mercilessly immolated or ritualized. They are cut once when stretched at the neck with a ritual cutlass or knife and once this is done, it is believed, prayer to the god is answered. One of the significance to this memorable occasion is to help indigenes succeed in their various professions and careers in life, ward-off evils, accidents, premature deaths, calamities and misfortune from the land. It is also marked to signify unity among the people, love in the families, and abundance of wealth, properties and good luck in coming seasons. No year must pass by without being celebrated. In Ife and other Yoruba settlements, the Ogun festival is called 'Olojo' usually celebrated almost the same time with the same significance and of course, in the same man (Johnson, 1921). An average traditional Ondo man celebrates Ogun anytime an issue calls for it, particularly, when there is need for a journey to prevent accident, clear the roads of evils and guarantee utmost safety throughout. He also does to show indebtedness to Ogun, the god of metals and technology to create and sustain things for the good of its own people. Ogun was a man who lived as a great warrior and blacksmith but died gallantly several centuries back and was later promoted to a diety. The Ondo people attach great importance to the festival than other festivals, thereby, making it the chief festival and arch-culture (Johnson, 1921). Major symbols and identity of Ogun includes fire, blood, cutlass, palm fronds and iron.

Myths and legend confirm that Ogun was a chief diety, who lived a great, warrior-like hunting life who used his implements to clear impenetrable way in the thick evil forest that no one else could do, hence, he was called 'Osin-Imole' (Chief among the divinities). As a ruthless deity, he lived in seclusion at the top of the hill where he went on hunting, until he retreated to a permanent settlement, after a prolonged seclusion, in a garment of fire and blood, with palm fronds to cover himself from the community that could not withstand his stand and appearance. He later headed to Ire where he was made a king, hence, the name Ogun Onire (Ogun, the lord of Ire) was accorded him (Olupona, J. K., 1991; Bascom, W. R., 1965; Please, see article in Journal of Religion in Africa 22(33): 279-280). Apart from Ogun, there are other deities worshipped by the Ondo people like Sango Oko Oya (God of Thunder husband of Oya), Egungun festival (the dead ancestors), Oro festival (the dead ancestors), King's festival (Odun Oba) etc. The Ondo people possess significant values like unique monumental traditional marriages which take weeks to complete with rites before a youth gets married in the community, expensive burial rites involving lineage members with drumming, cooking of bean cakes (Akara), palm-wine, preparations of pounded yam and cutting of expensive clothes called 'Aso Ebi' uniform, most especially, if the death involves an aged person or a chief. This is greeted with lots of fun fares and festivities attracting crowds of friends and relations and others (Olupona, 1991).

\section{SUMMARY AND CONCLUSION}

This research was undertaken to unveil the historical antecedents of the Ondo kingdom and its people, through a descriptive-analytical approach that is investigative and explorative in nature. The research 
surveyed the origin of the kingdom with particular interest in its culture and politics. The researchers worked within the limitation of their study by describing, the origin of the Ondo kingdom, its antecedents and the period of its existence till present, spanning over five hundred years and above (that is about six centuries ago). The study engaged a methodological and comparative analysis approach for study into the political process of the kingdom with a comparison of the modern day states' political systems. The political structure was found to be highly organized, centralized but with some substantial elements of devolution, characterizing a governmental process with many levels of authority, but, with reference to the deity represented by (the Osemawe). The study surveyed also the cultural legacies of the people and what they worship and what laws they keep and how they keep them ultimately. The study is a contribution to available literature on the culture and lives of the Ondo people and their rich traditional political system. It will however provide avenues for further research for future researchers on the subject-matter.

\section{REFERENCE LIST}

Abimbola, W. (1977). The Study of Yoruba Literature: An Assessment, An Inaugural Lecture, University of Ife.

Ajulo, E. B. (2000). Meaning (Dis) Equivalence in Translations: Exemplifying with Two Literary TextsSoyinka's A Forest of a Thousand Dacmons and Fagunwa's Ogboju Ode Ninu Igbo Irunmale, University of Jos.

Babalola, S. A. (1966). The Content and Form of Yoruba ljala, Oxford: Clarendon Press.

Bascom, W. R. (1965). ‘Folklore Research in Africa' Journal of American Folklore LXXVII (303)

Clarke, K. W. and Clarke, M. W. (1963). Introducing Folklore, Rhineland and Winston Inc. NY.

Crowther, S. A. (1852). A Grammar and Vocabulary of Yoruba Language, London Seclays.

Eades, J. S. (1980). The Yoruba Today, Cambridge University Press, Cambridge.

Johnson, S. (1921). The History of the Yorubas: From the Earliest Times to the Beginning of the British Protectorate. (Ed.) By Johnson, Obadian, Lagos. C.M.S. (Nigeria) Bookshops, Lowe and Brydone Printers, London.

Lloyd, P.C. (1962). Yoruba Land Law: Oxford University Press, London.

Olupona, J. K. (1991). Kingship, Religion and Rituals in a Nigerian Community: A Phenomenological Study of Ondo Yoruba Festivals, (Stockholm Studies in Comparative Religion, No. 28), Stockholm, Almqvist and Wiksell Int'l; ISBN 9122013822, pp. 195)

Omotosho O. F, Ologbenla D. K and Ezire, A. H. (2016). Nationhood and the Quest for National Development: The Gambia's Experience under the Second Republic (1994-2015), A Conference Proceeding at the SOCIOINT $20163^{\text {rd }}$ International Conference on Education, Social Sciences and Humanities, May 23-25,2016, Istanbul, Turkey

Omotosho, O. F., Ologbenla, D. K. and Omotosho, O. A. (2016). What Has Changed in Our Land: "A Critical Assessment of the Extinction of Indigenous Yam Crop in a Rural Okeigbo Community in Ondo State of South-Western Nigeria". An Article already accepted for a Peer Review Journal Publication.

Please see, Article in Journal of Religion in Africa 22(3): 279-280. December, 1991. DOI: 10: $1163 / 157006692 \times 00266$

\section{Please see,}

http://ekimogundescendant.org/index.php?option=com/content\&view=article\&id=117:ondo-kingdomlandmarks

http://kwekudee-tripdownmemorylane.blogspot.com/2014/09/ondo-people-forest-agriculturist.html http://ekimogundescendant.org http://repos.unijos.edu.ng/jspui/bitsream/123456789/157/1/yoruba\%20ondo\%20proverb.pdf http://news2.onlinenigeria.com/news/general/42431-500-years-the-Osemawe-Dynasty.html 